\title{
Effect of chitosan-based solutions applied as edible coatings and water glazing on frozen salmon preservation - A pilot-scale study
}

\author{
Nuno M. Soares, Tânia S. Mendes, António A. Vicente* \\ IBB - Institute for Biotechnology and Bioengineering, Centre of Biological Engineering, University of Minho, Campus de Gualtar, 4710-057 Braga, Portugal
}

\section{A R T I C L E I N F O}

\section{Article history:}

Received 16 January 2013

Received in revised form 9 May 2013

Accepted 16 May 2013

Available online 7 June 2013

\section{Keywords:}

Glazing

Edible coating

Shelf-life

Frozen salmon

Chitosan

Pilot-scale

\begin{abstract}
A B S T R A C T
The aim of this research was to compare the effect of chitosan solutions on frozen salmon preservation with that of water glazing. For this purpose, three chitosan solutions $(0.25 \%, 0.50 \%$ and $0.75 \% \mathrm{w} / \mathrm{v})$ and water were applied in different amounts $(6 \%, 8 \%$ and $11 \%$ of coated fillet weight) directly on the surface of frozen salmon. In order to accelerate the deterioration processes, salmon was stored during 14 weeks at $-5{ }^{\circ} \mathrm{C}$. Microbial and chemical indices were used to assess deterioration during storage and the coating stability was evaluated through weight loss measurements. The results obtained showed that chitosan coatings can be a good barrier to protect frozen fish from deterioration. Microbial growth, assessed by total viable counts (TVC), and total volatile basic nitrogen (TVB-N) were maintained below the maximum limits recommended which are $5 \times 105 \mathrm{CFU} / \mathrm{g}$ and $35 \mathrm{mg}$ nitrogen/100 g fish, respectively. The use of $0.50 \%$ and $0.75 \%$ chitosan solutions generally demonstrated to be more efficient in preventing salmon weight loss.
\end{abstract}

(c) 2013 Elsevier Ltd. All rights reserved.

\section{Introduction}

The search for healthier products is an increasingly important drive to consumers' food choices. Fish is much known for its richness in several nutrients as protein, vitamins $\mathrm{D}$ and $\mathrm{E}$, selenium and long-chain polyunsaturated fatty acids, such as omega-3. Thus fish is perceived as an important part of a healthy diet among nutrition and food scientists as well as consumers (Brunsø et al., 2008; Doré, 2008). In the last decades, the consumption of this food group increased and became available to consumers far away from the coastal areas. However, fresh fish is among the most perishable foodstuffs due to various intrinsic factors, such as high water-holding capacity, neutral pH values, tissue enzymes, low connective tissue content and natural microbial contamination (Kilincceker et al., 2009). Thus, the improvement of food preservation techniques in order to carry fish safely to the consumers and retain its organoleptic characteristics is a major concern of seafood industry.

Freezing is a common option among the methods existing for long term preservation of fish. This process inhibits microbial growth and slows down the enzymatic activity as well as preserves taste and nutritional value (Gonçalves and Gindri Junior, 2009; Jiang and Lee, 2004). Despite freezing preservation efficiency, some undesirable changes such as lipid oxidation, surface dehydration and protein denaturation might occur during frozen storage, nega-

\footnotetext{
* Corresponding author. Tel.: +351 253604419; fax: +351253678986.

E-mail address: avicente@deb.uminho.pt (A.A. Vicente).
}

tively affecting the nutritional and sensory quality of frozen fish, thus influencing the acceptability of the product. In seafood industry, glazing is a technology widely used to protect the processed frozen fish during storage. This process consists in creating a water coating on the surface of frozen product by spraying or dipping the product in water. This coating reduces the rate of oxidation by excluding air from the product surface. In addition, it retards the freezer burn since the glaze will sublime instead of the tissue water. The amount of glaze depends on the product size and shape, the water and product temperature and the glazing time (Johnston et al., 1994). Typically, the glaze content ranges from $8 \%$ to $12 \%$ of the gross weight, though larger amounts are sometimes used (Jacobsen and Fossan, 2001). The determination and control of glaze content is very important in seafood industry, since small quantities of glaze might not protect the product efficiently and excessive amounts may cause economic loss for consumers.

Nevertheless, temperature fluctuations often occur during handling and transport of frozen fish which cause losses in the glaze, reducing its protective effect. Thus, it is of great importance to develop coatings that combine the mentioned positive features of glaze with a longer protection.

According to Rodriguez-Turienzo et al. (2011), lipid oxidation and/or moisture losses during frozen storage of fish can be reduced by applying edible coatings on the surface of the product since they act as a barrier against moisture and oxygen transfer, helping to maintain the quality of frozen food and extending shelf life. Depending on the desired characteristics, various materials might be used, singly or in combination, to prepare edible coatings. As 
a general rule, proteins are utilized to provide mechanical stability, polysaccharides are applied to control oxygen and other gases transmission and fats are used to reduce water transfer (Pavlath and Orts, 2009). Foods with a high level of unsaturated fats which are easily oxidized, such as Atlantic salmon, would be best protected by a polysaccharide barrier. Chitosan-based coatings have been tested by several authors in an attempt to maintain quality and prolong shelf life of fish products (Rodriguez-Turienzo et al., 2011; Sathivel et al., 2007; Souza et al., 2010). This non-toxic, biodegradable, biofunctional and biocompatible polysaccharide has been reported to present antimicrobial and antifungal activity while also being able to incorporate substances such as vitamins and minerals (Dutta et al., 2009; Leroi et al., 2008).

Usually, assessing frozen fish freshness is a time consuming activity because it requires analysis during long periods. In order to accelerate this evaluation, several authors have developed models to predict quality deterioration and shelf life of a variety of products during frozen storage (Gonçalves et al., 2011; Martins et al., 2005). Tsironi et al. (2009) have investigated and modeled the effect of variable storage temperatures $(-5,-8,-12$ and $-15^{\circ} \mathrm{C}$ ) on shelf life and quality characteristics of frozen shrimp and demonstrated the applicability of the models in the cold chain. According to their results, storage temperature highly influences deterioration processes with higher temperatures leading to shorter shelf life.

The aim of this work was to compare the protective effect of different chitosan-based coatings, applied directly on frozen salmon, with that of a water coating. In order to understand the contribution of coating content to the overall protective effect, different amounts of coating were also tested. To accelerate the deterioration processes, treated salmon was stored during 14 weeks at $-5{ }^{\circ} \mathrm{C}$. Fish processing and sample preparation were performed at pilot-scale in an industrial environment.

\section{Materials and methods}

\subsection{Fish samples}

Frozen and vacuum packaged Atlantic salmon (Salmo salar) fillets were kindly provided by Lerøy Seafood Group (Bergen, Norway). After unpacking, an industrial vertical bone sawing machine was used to cut the salmon fillets in loins with the dimensions $10 \mathrm{~cm} \times 5 \mathrm{~cm} \times 2-3 \mathrm{~cm}$ and an average weight of $79.1 \pm 5.2 \mathrm{~g}$. This process was carried out in a refrigerated room to minimize temperature uptake and the salmon samples were stored at $-18{ }^{\circ} \mathrm{C}$ until further use.

\subsection{Coating solutions}

Coating solutions with different chitosan (Golden-shell Biochemical Co. Ltd. (China) with $91 \%$ degree of deacetylation) concentrations $(0.25 \%, 0.50 \%$ and $0.75 \% \mathrm{w} / \mathrm{v})$ were prepared by adding the corresponding mass in a $1 \% \mathrm{v} / \mathrm{v}$ lactic acid and stirring at room temperature until completely dissolved. Water was also used as coating - water glazing.

\subsection{Coating application and storage}

The frozen fish pieces $\left(-18^{\circ} \mathrm{C}\right)$ were weighted, dipped in chitosan coating solutions $\left(5^{\circ} \mathrm{C}\right)$ or in water $\left(0^{\circ} \mathrm{C}\right)$, for different dipping times, drained for $2 \mathrm{~min}$ and weighted again. This coating process was carried out in a pilot-scale glazing tank; samples were collected from the tank with a stainless steel mesh, in order to minimize the interference with the amount of coating applied. Coating uptake was calculated according to Eq. (1), where $W_{\text {salmon }}$ and $W_{i}$ represent the weight of the salmon portion before and after the coating application, respectively. Samples groups with an average coating uptake of $6.1 \pm 0.6,8.1 \pm 0.7$ and $10.5 \pm 0.9$ (all values in wt\%) were obtained. Salmon pieces belonging to the control group were left untreated.

Coating uptake $(\%)=\frac{W_{i}-W_{\text {salmon }}}{W_{i}} \times 100$

All samples were individually packed in polyethylene freezer bags and stored at $-5.0 \pm 0.6{ }^{\circ} \mathrm{C}$ for 14 weeks. This temperature was monitored and registered every $20 \mathrm{~min}$ by using a data logger (DS1923 temperature/humidity logger iButton ${ }^{\circledR}$, Dallas Semiconductors, USA).

During storage, samples were taken in triplicate and separately analyzed to assess fish quality.

\subsection{Coating loss}

After the storage period, samples were weighted $\left(W_{f}\right)$ and the coating loss was determined by the following equation;

Coating loss $(\%)=\frac{W_{f}-W_{i}}{\left(W_{i}-W_{\text {salmon }}\right)} \times 100$

\subsection{Weight loss}

The control salmon pieces were left untreated without addition of any coating. In this case, weight loss was calculated by following the next equation where $W_{\text {salmon, } i}$ and $W_{\text {salmon } f}$ represent the weight of the salmon pieces before and after the storage period, respectively.

Weight loss $(\%)=\frac{W_{\text {salmon } f}-W_{\text {salmon }, i}}{W_{\text {salmon } f}} \times 100$

\subsection{Microbial analysis}

Total viable counts (TVC) were estimated according to the procedure described in the standard ISO 4833 (2003).

\subsection{Chemical analysis}

\subsubsection{Determination of $\mathrm{pH}$}

A $5 \mathrm{~g}$ portion of each sample was homogenized with $50 \mathrm{~mL}$ of ultrapure water in a mixer/blender for $30 \mathrm{~s}$ and the $\mathrm{pH}$ value of the mixture was measured using a digital pH meter (HI 8711E, HANNA Instruments, Italy).

\subsubsection{Determination of 2-thiobarbituric acid (TBA)}

The 2-thiobartbituric acid (TBA) value was evaluated colorimetrically using the method of Pokorny and Dieffenbacher (1989). Briefly, a $500 \mathrm{mg}$ portion of each sample was weighed and added to $25 \mathrm{~mL}$ of 1-butanol. Using a pipette, $5 \mathrm{~mL}$ of the sample solution and $5 \mathrm{~mL}$ of TBA reagent were transferred to a dry test tube. The test tube was stoppered, thoroughly mixed using a vortex, and placed in a thermostated water bath at $95^{\circ} \mathrm{C}$ for $120 \mathrm{~min}$. After cooling in running tap water, the optical density was measured at $530 \mathrm{~nm}$ in a $10 \mathrm{~mm}$ quartz cell, using distilled water in the reference cell, in a Jasco V-560 UV/Vis spectrophotometer (Japan). A reagent blank was run at the same time.

\subsubsection{Determination of total volatile basic nitrogen (TVB-N)}

The total volatile basic nitrogen (TVB-N) value was determined according to the procedure described in the standard NP 2930 (2009). 


\subsubsection{Determination of $K$ value}

The $K$ value was estimated according to the method of Ryder (1985) as described by Souza et al. (2010). Briefly, a $5 \mathrm{~g}$ sample was homogenized with $25 \mathrm{~mL}$ of chilled $0.6 \mathrm{~mol} / \mathrm{L}$ perchloric acid at $0{ }^{\circ} \mathrm{C}$ for $1 \mathrm{~min}$. The homogenate was centrifuged (EBA 20, Hettich zentrifugen, Germany) at $3000 \times \mathrm{g}$ for $10 \mathrm{~min}$, and $10 \mathrm{~mL}$ of the supernatant adjusted to $\mathrm{pH}$ 6.5-6.8 with $1 \mathrm{~mol} / \mathrm{L}$ potassium hydroxide using a digital pH meter (HI 8711E, HANNA Instruments, Italy). After standing at $1{ }^{\circ} \mathrm{C}$ for $30 \mathrm{~min}$, the potassium perchlorate that precipitated was removed by filtration using a Whatman nr.1 filter paper. The filtrate was diluted to $2 \mathrm{~mL}$ with ultrapure water, passed through a $0.20 \mu \mathrm{m}$ Fioroni membrane, and stored at $-80^{\circ} \mathrm{C}$ until subsequent analysis using High Performance Liquid Chromatography (HPLC).

\subsection{Statistical analysis}

Mean values of three independent determinations were reported and the statistical significance of differences among treatment means was evaluated by analysis of variance (ANOVA) followed by the Tukey test at 95\% significance level. Data were evaluated statistically using the software STATISTICA version 7.0 (StatSoft Inc. 2004, USA).

\section{Results and discussion}

\subsection{Coating loss}

The weight of coating lost during storage of salmon samples treated with water/chitosan solutions and three different coating uptakes was evaluated in order to determine which coating had a higher loss rate (Fig. 1 ).

The equations representing the trend lines obtained for each treatment are presented in Table 1.

As can be seen by the positive slope of the trend lines (Table 1), the amount of coating lost increased steadily during the storage period for all treatments. Analyzing each type of coating applied, it was clear that the higher the coating uptake, the higher the coat- ing loss, except for samples treated with $0.25 \%$ chitosan solution. In that case, the weight of coating lost for $6 \%$ and $8 \%$ coatings was very similar. The fact that higher weight loss occurred with higher coating uptakes may be related with coating thickness. In thicker coatings, water molecules on the surface are more distant from the center of the product, where the temperature is lower, being more susceptible to temperature fluctuations and eventual phase transitions. Comparing the different types of coating for the same coating uptake, the higher loss corresponded to water and $0.75 \%$ chitosan coatings. The use of $0.25 \%$ and $0.50 \%$ chitosan coatings seemed to be the best option among the treatments studied to decrease the rate of coating loss, especially when $6 \%$ and $8 \%$ of coating were applied.

Coating loss in percentage of coating applied was also analyzed. With respect to type of coating applied, the coating loss on samples without chitosan was apparently greater than the loss in samples containing chitosan, although this effect was more pronounced in $6 \%$ and $8 \%$ coating uptakes. However, there were no statistically significant differences that supported this evidence due to high standard deviations obtained. The lower percentage of coating loss in samples treated with chitosan solutions might be due to the rheological properties of the polymer.

According to Hwang and Shin (2000), the viscosity of chitosan solutions increases with polymer concentration, which may have increased the toughness of chitosan coatings. However, a direct relation between the increase in chitosan concentration and coating loss was not identified. Although the coatings applied were only partially lost $(1 \pm 0.2 \mathrm{~g}$ in the worst case, which represents a loss of $19.4 \pm 3.0 \%$ ) it does not ensure that the salmon samples remained completely protected. According to Johnston et al. (1994), the corners and edges of glazed fish pieces are more susceptible to dehydration and can be damaged long before the overall weight loss reaching the weight of glaze applied. Coating application does not allow the elimination of fish dehydration, it just retards its occurrence.

Table 2 shows the predicted time to reach $50 \%$ of coating loss for all treatments, considering a linear trend for the 14 weeks analyzed. According to these forecasts, the samples coated with $6 \%$ of
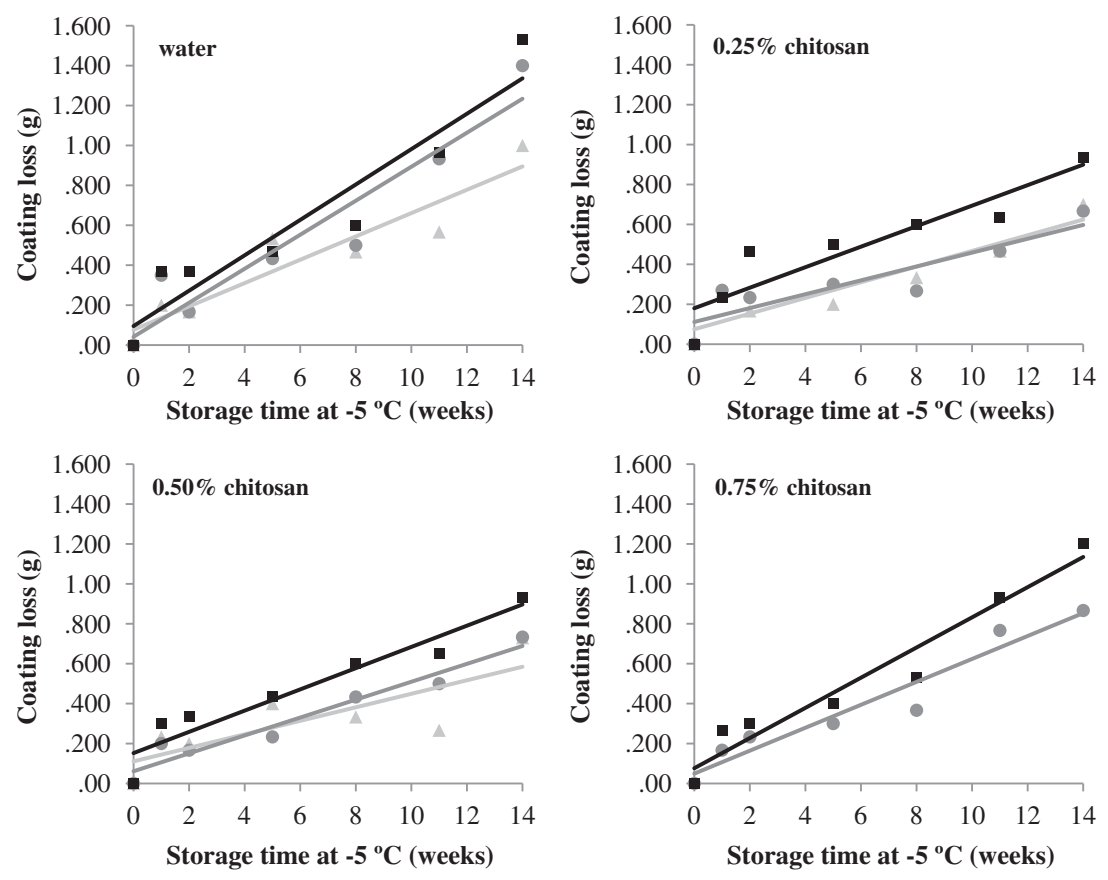

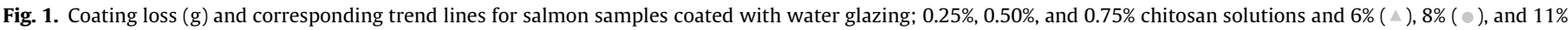
(a) coating uptakes during 14 weeks of storage at $-5^{\circ} \mathrm{C}$. 
Table 1

Equations of trend lines for coating loss ( $y$, in $\mathrm{g}$ ) of salmon samples during storage time ( $x$, in weeks), for 14 weeks at $-5{ }^{\circ} \mathrm{C}$.

\begin{tabular}{|c|c|c|c|}
\hline \multirow[t]{2}{*}{ Treatment } & \multicolumn{3}{|l|}{ Trendlines } \\
\hline & $6 \%$ & $8 \%$ & $11 \%$ \\
\hline Water & $\begin{array}{l}y=0.0584 x+0.0767 \\
R^{2}=0.8817\end{array}$ & $\begin{array}{l}y=0.0852 x+0.0414 \\
R^{2}=0.9024\end{array}$ & $\begin{array}{l}y=0.0887 x+0.095 \\
R^{2}=0.9008\end{array}$ \\
\hline 0.25\% Chitosan & $\begin{array}{l}y=0.0392 x+0.0749 \\
R^{2}=0.8553\end{array}$ & $\begin{array}{l}y=0.347 x+0.1114 \\
R^{2}=0.8007\end{array}$ & $\begin{array}{l}y=0.0514 x+0.1799 \\
R^{2}=0.8431\end{array}$ \\
\hline 0.75\% Chitosan & - & $\begin{array}{l}y=0.0575 x+0.0491 \\
R^{2}=0.9341\end{array}$ & $\begin{array}{l}y=0.0756 x+0.0762 \\
R^{2}=0.9477\end{array}$ \\
\hline
\end{tabular}

Table 2

Predicted time to reach $50 \%$ of coating loss.

\begin{tabular}{llll}
\hline \multirow{2}{*}{ Treatment } & \multicolumn{3}{l}{ Time to 50\% coating loss (weeks) } \\
\cline { 2 - 4 } & $6 \%$ & $8 \%$ & $11 \%$ \\
\hline Water & 42 & 48 & 60 \\
$0.25 \%$ Chitosan & 58 & 92 & 82 \\
$0.50 \%$ Chitosan & 74 & 87 & 82 \\
$0.75 \%$ Chitosan & - & 56 & 60 \\
\hline
\end{tabular}

water solution would be the first losing $50 \%$ of coating applied, in about 42 weeks, whereas $0.25 \%$ chitosan solution with $8 \%$ coating uptake would retard this effect up to 92 weeks. A relation between the delay of coating loss and the chitosan concentration or amount of coating applied was not clearly identified, although the coating loss was retarded for water and $0.75 \%$ chitosan coatings by increasing the coating uptake and for $6 \%$ coatings by increasing chitosan concentration.

If fish is not protected by coating application, the tissue water sublimes instead of the coating.

Fig. 2 shows the weight loss of salmon samples from the control group (uncoated) during storage. After 14 weeks of frozen storage, salmon pieces lost about $0.7 \pm 0.2 \%$ of their initial weight.

Although this is a reduced value, it is important to underline that weight loss was evaluated with salmon in a frozen state. After thawing, loss of water from the fish muscle (drip loss) also occurs, leading to negative changes in texture and color (Blond and Meste, 2004). According to Johnston et al. (1994), the rate of weight loss might vary with several factors such as temperature, temperature fluctuation, humidity, and shape and size of the product. Usually, moisture loss is more pronounced when temperature fluctuations occur (Gonçalves and Gindri Junior, 2009) therefore, the low values of weight and coating loss obtained might be explained by a wellcontrolled storage temperature. During the 14 weeks the salmon



Fig. 2. Weight loss (\%) of salmon samples from the control group during 14 weeks of storage at $-5^{\circ} \mathrm{C}$. Each bar represents the mean \pm standard deviation of three replications. Different letters indicate a statistically significant difference (Tukey test, $p<0.05$ ). pieces were stored at $-5.0 \pm 0.6{ }^{\circ} \mathrm{C}$ with maximum temperature amplitude of $2^{\circ} \mathrm{C}$

\subsection{Total viable counts}

Microbial activity is the main factor limiting the shelf life of fresh fish, an estimation of the total viable counts (TVC) has been used as an acceptability index in standards, guidelines and specifications (Olafsdóttir et al., 1997). The initial total viable count (TVC) value of salmon was $3.8 \pm 0.5 \log _{10} \mathrm{CFU} / \mathrm{g}$ and the evolution of this index during storage is shown in Fig. 3.

Slight variations in TVC occurred during the storage period for all treatments. However, the microbiological limit of $5 \times 10^{5}$ $\mathrm{CFU} / \mathrm{g}\left(5.7 \log _{10} \mathrm{CFU} / \mathrm{g}\right.$ ) recommended by (ICMSF, 1986) for frozen fish of good quality was never exceeded. There was no evidence that the type of coating applied influences the microbiological growth as well as the amount of coating applied. Microbiological growth is known to be inhibited by freezing temperature. According to Jay et al. (2005), the minimal reported growth temperature for foodborne microbial species is $-5{ }^{\circ} \mathrm{C}$ for Vibrio spp. and Cladosporium cladosporiodes. The slight variations observed during the 14 weeks might be related with the variability inherent to fish samples.

\section{3. $\mathrm{pH}$ Value}

Changes in $\mathrm{pH}$ values during storage for $6 \%, 8 \%$ and $11 \%$ coating uptake are shown in Fig. 4. The initial $\mathrm{pH}$ value of salmon samples was $6.27 \pm 0.15$. After 14 weeks of frozen storage, the $\mathrm{pH}$ of uncoated samples was $6.14 \pm 0.02$, whereas for samples coated with water the $\mathrm{pH}$ values were $6.09 \pm 0.04,6.18 \pm 0.07$, and $6.21 \pm 0.02$ for $6 \%, 8 \%$ and $11 \%$ of coating uptake respectively. It was evidenced that samples coated with water had apparently higher $\mathrm{pH}$ values during almost all storage when compared with uncoated and coated with chitosan samples although there was no statistically significant differences for all cases. Salmon samples coated with chitosan revealed final $\mathrm{pH}$ values slightly lower than samples coated with water and uncoated samples. The amount of coating applied did not show a significant influence on the evolution of $\mathrm{pH}$. According to Singh and Balange (2005) the decrease in $\mathrm{pH}$ of fish samples might result from protein breakdown and release of phosphoric and lactic acids occurring during freezing and thawing processes. However, if these processes had occurred, the $\mathrm{pH}$ of uncoated samples should have decreased too. Thus, the reduction of $\mathrm{pH}$ values of samples coated with chitosan may be related with migration from the coating itself, which has an acid $\mathrm{pH}$ value (2.6), to fish muscle or with the inability to completely remove the coating before $\mathrm{pH}$ measurement. A study performed by Sathivel et al. (2007) also demonstrated that initial pH value of salmon fillets did not vary for uncoated samples when stored at $-35^{\circ} \mathrm{C}$ for 8 months. In addition, samples uncoated and coated with distilled water had a $\mathrm{pH}$ value slightly higher than samples coated with lactic acid and $1 \%$ chitosan. 



Fig. 3. Total viable counts ( $\log 10 \mathrm{CFU} / \mathrm{g}$ ) for salmon samples of control group ( $\square$ ) and coated with water $(\square), 0.25 \%$ chitosan $(\square), 0.50 \%$ chitosan ( $\square$ ), and $0.75 \%$ chitosan ( $\mathbf{\square})$ during 14 weeks of storage at $-5{ }^{\circ} \mathrm{C}$, for different glazing percentages (a) $6 \%$, (b) $8 \%$ and (c) $11 \%$. Each bar represents the mean \pm standard deviation of three replications. Different letters at the same week indicate a statistically significant difference (Tukey test, $p<0.05$ ). The horizontal line represents the limit recommended by ICMSF (1986) which is $5 \times 105 \mathrm{CFU} / \mathrm{g}$.

\subsection{Thiobarbituric acid value}

At temperatures below $0{ }^{\circ} \mathrm{C}$, oxidation rather than microbial activity becomes the major spoilage factor and particularly important for shelf life. The TBA assay has been widely used to evaluate lipid oxidation in food (Guzmán-Chozas et al., 1998; Olafsdóttir et al., 1997). The initial TBA value of salmon was $0.03 \pm 0.01$ and changes of this parameter during storage for $6 \%, 8 \%$ and $11 \%$ coating uptake are shown in Fig. 5.

Although in general this index remained stable during the storage period, in the last week the TBA value for uncoated samples doubled. For coated samples it seemed that the increase was generally smaller, especially when $0.50 \%$ and $0.75 \%$ chitosan coatings were applied, however, there were no statistically significant differences supporting that conclusion. A study performed by Sathivel et al. (2007) demonstrated that distilled water and $1 \%$ chitosan coatings were effective in reducing lipid oxidation in salmon fillets stored at $-35{ }^{\circ} \mathrm{C}$ for 8 months when compared with uncoated sam-
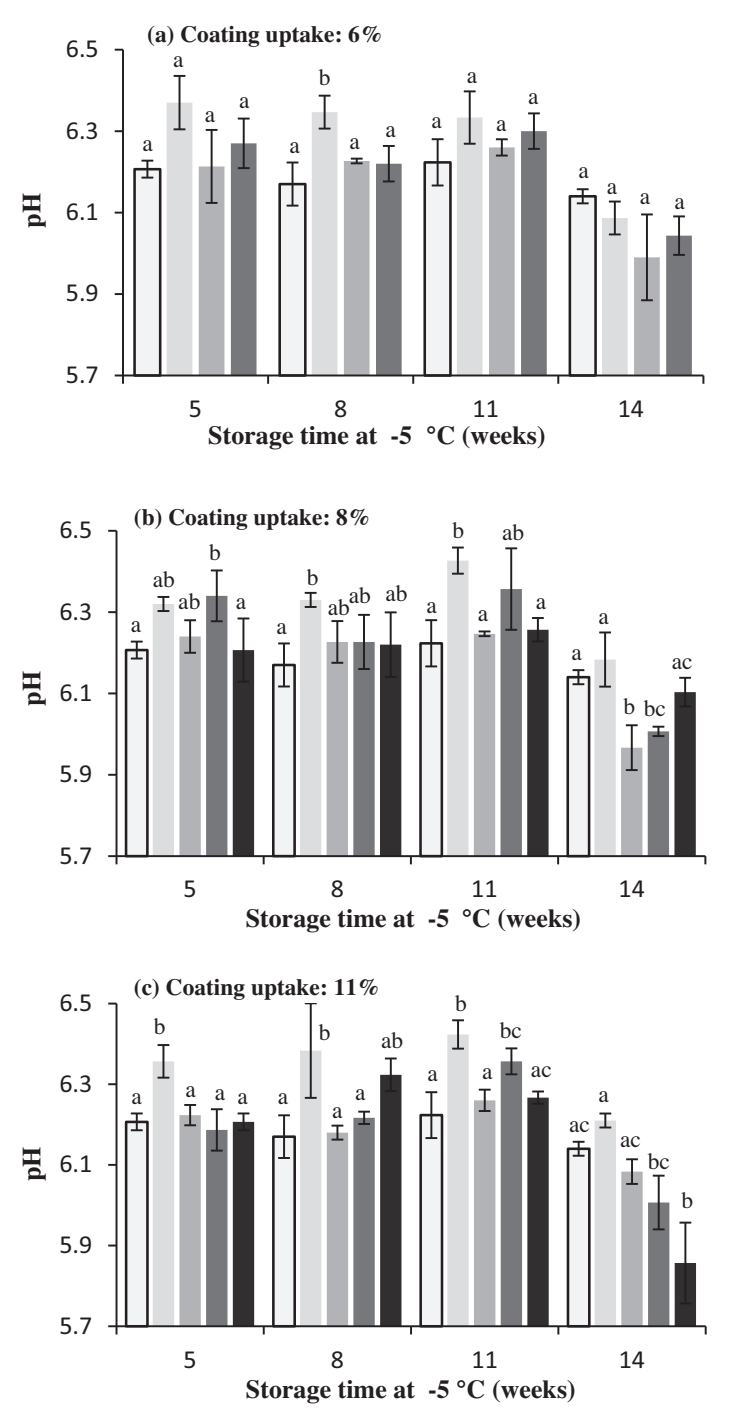

Fig. 4. pH Values for salmon samples of control group ( $\square$ ) and coated with water ( $), 0.25 \%$ chitosan ( $\square$ ), $0.50 \%$ chitosan ( $\square$ ), and $0.75 \%$ chitosan ( $\square$ ) during 14 weeks of storage at $-5{ }^{\circ} \mathrm{C}$, for different glazing percentages (a) $6 \%$, (b) $8 \%$ and (c) $11 \%$. Each bar represents the mean \pm standard deviation of three replications. Different letters at the same week indicate a statistically significant difference (Tukey test, $p<0.05$ ).

ples. Both coatings were resistant to oxygen diffusion retarding lipid oxidation, however, the protective effect of chitosan was more pronounced, perhaps due to its antioxidant properties reported by Shahidi et al. (1999). The amount of coating applied had no influence on lipid oxidation control, which might mean that it is not necessary to use high amounts of coatings to inhibit lipid oxidation.

\subsection{Total volatile basic nitrogen}

The total volatile base nitrogen (TVB-N) is an indicator of the presence of nitrogenous materials resulting from the action of proteolytic bacteria (Kilincceker et al., 2009). The measurements of this parameter are used as an acceptability index for certain fish species (EU Directive 95/149). The initial TVB-N value was $7.2 \pm 1.3 \mathrm{mg}$ nitrogen/100 g salmon. After 14 weeks of frozen storage, the TVB-N of the control group was $6.8 \pm 1.1$ and for coated samples the TVB-N values are presented in Table 3. The TVB-N values remained stable for all treatments far below the $35 \mathrm{mg}$ nitrogen/100 $\mathrm{g}$ fish established as limit of acceptability of salmon by 

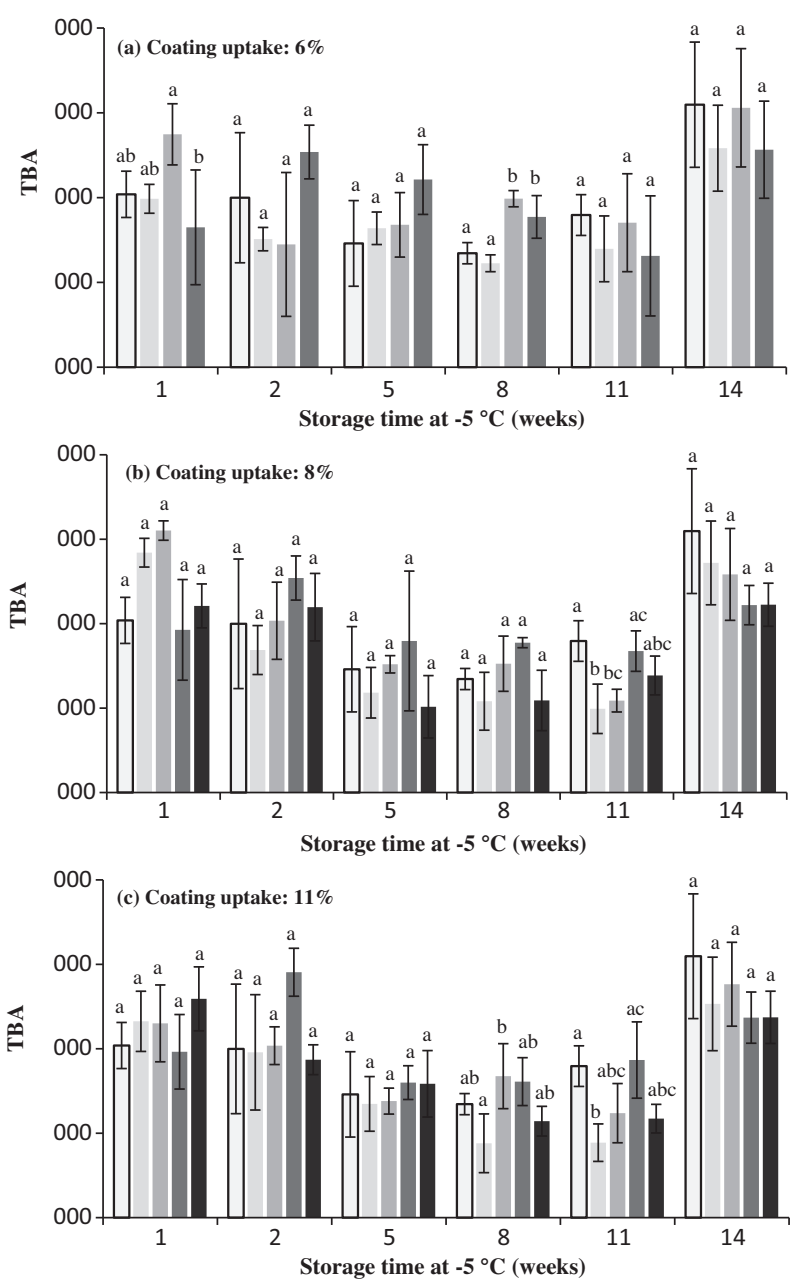

Fig. 5. Thiobarbituric acid (TBA) values for salmon samples of control group ( $\square$ ) and coated with water $(\square), 0.25 \%$ chitosan $(\square), 0.50 \%$ chitosan $(\square)$, and $0.75 \%$ chitosan (ם) during 14 weeks of storage at $-5{ }^{\circ} \mathrm{C}$, for different glazing percentages (a) $6 \%$, (b) $8 \%$ and (c) $11 \%$. Each bar represents the mean \pm standard deviation of three replications. Different letters at the same week indicate a statistically significant difference (Tukey test, $p<0.05$ ).

Table 3

Total volatile basic nitrogen (TVB-N) values for salmon samples after 14 weeks of storage at $-5{ }^{\circ} \mathrm{C}$; standard deviation corresponds to three replications; no statistically significant difference were detected (Tukey test, $p<0.05$ ).

\begin{tabular}{llll}
\hline \multirow{2}{*}{ Treatment } & \multicolumn{3}{l}{ TVB-N (mg nitrogen/100 g salmon) } \\
\cline { 2 - 4 } & $6 \%$ & $8 \%$ & $11 \%$ \\
\hline Water & $5.92 \pm 2.06$ & $8.80 \pm 2.36$ & $6.97 \pm 1.10$ \\
$0.25 \%$ Chitosan & $5.05 \pm 0.66$ & $6.08 \pm 0.77$ & $5.73 \pm 0.39$ \\
$0.50 \%$ Chitosan & $6.11 \pm 1.68$ & $7.10 \pm 3.28$ & $6.31 \pm 1.32$ \\
$0.75 \%$ Chitosan & - & $5.31 \pm 1.75$ & $7.71 \pm 0.85$ \\
\hline
\end{tabular}

EU Directive 95/149 (1995). These low values indicate a good state of fish preservation. Gonçalves and Gindri Junior (2009) evaluated the influence of different glazing percentages on TVB-N evolution of frozen shrimp stored at $-18{ }^{\circ} \mathrm{C}$ during 180 days and verified an increase only after 90 days. Probably, the time of salmon storage was not long enough to identify differences among the various coatings since the activity of spoilage bacteria and endogenous enzymes is slowed down at low temperatures and, as the low TVC values mentioned above indicated, the salmon used in this study was in good condition.

\section{6. $K$ value}

Adenosine triphosphate (ATP) degradation by endogenous enzymes in fish during the early stages of storage was found to parallel the loss of fish freshness. $K$ value, a measure of adenine nucleotides and their degradation products has been used as a reliable indicator of freshness that is applicable for frozen fish (Olafsdóttir et al., 1997; Ryder, 1985). The effect of various chitosan concentrations on $K$ value evolution during storage for $6 \%, 8 \%$ and $11 \%$ coating uptake is shown in Fig. 6.

The initial $K$ value of salmon samples was $53.8 \pm 9.4 \%$ which indicates an advanced stage of ATP degradation. Souza et al. (2010) reported an initial $K$ value of $10.6 \%$ for fresh salmon fillets of the same species. Various factors as type of muscle, stress of fish during capture, and storage temperatures affect the $K$ value of fish (Huss, 1995; Souza et al., 2010). The difference between initial $K$ values obtained in both studies might be related with fish provenance and time elapsed prior to analysis. The salmon used in this study was from aquaculture and was previously filleted, packaged and frozen whereas fish used by the mentioned authors was obtained fresh. The $K$ index increased during the storage period nearly reaching $100 \%$ in all treatments. Between second and eighth weeks, salmon treated with $0.75 \%$ chitosan coating showed a slightly slower increase than the control group, however, the trend for the other coatings was very similar to that of untreated sam-
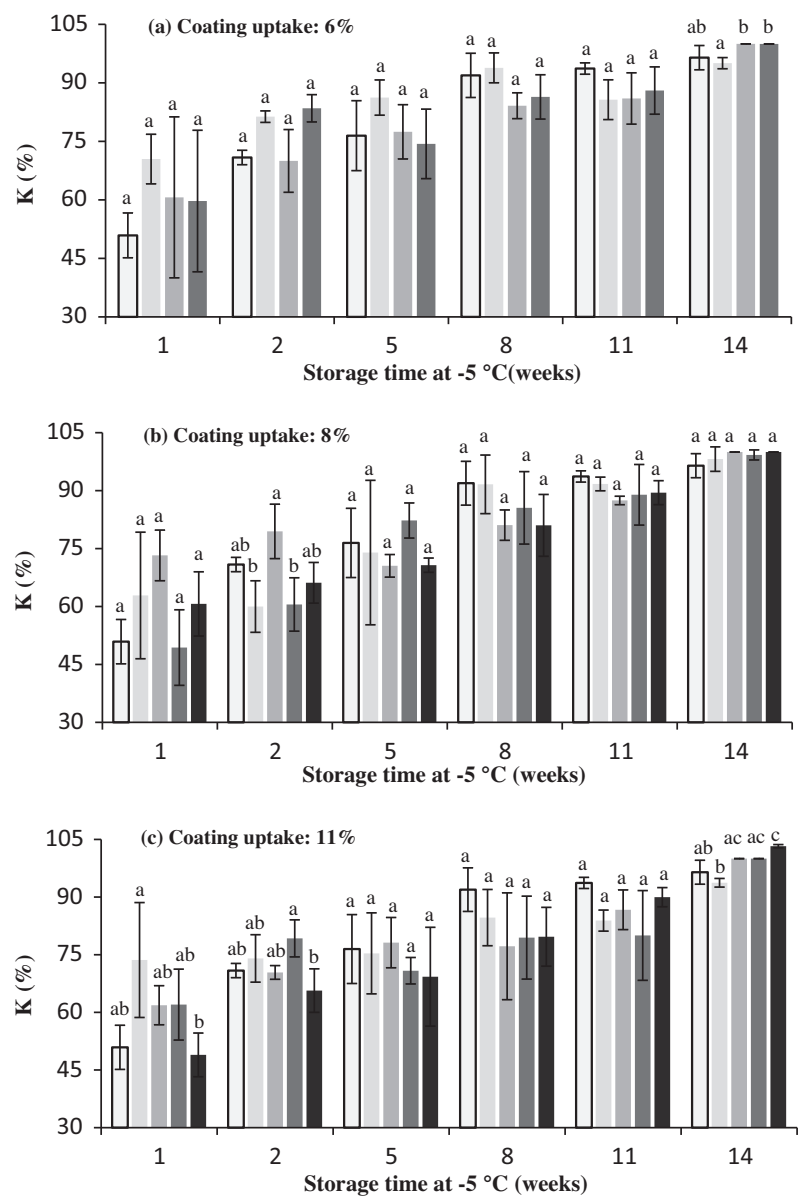

Fig. 6. $K$ values for salmon samples of control group $(\square)$ and coated with water $(\square)$, $0.25 \%$ chitosan ( $\square$ ), $0.50 \%$ chitosan ( $\square$ ), and $0.75 \%$ chitosan ( $)$ during 14 weeks of storage at $-5{ }^{\circ} \mathrm{C}$, for different glazing percentages (a) $6 \%$, (b) $8 \%$ and (c) $11 \%$. Each bar represents the mean \pm standard deviation of three replications. Different letters at the same week indicate a statistically significant difference (Tukey test, $p<0.05$ ). 
Table 4

Equations of trend lines for $K$ values ( $y$, in \%) of salmon samples during storage time ( $x$, in weeks) for 14 weeks at $-5^{\circ} \mathrm{C}$.

\begin{tabular}{|c|c|c|c|}
\hline \multirow{2}{*}{$\begin{array}{l}\text { Control } \\
\text { Treatments }\end{array}$} & \multicolumn{3}{|c|}{$\begin{array}{l}\text { Equations of trend lines } \\
y=3.2967 x+56.986\end{array}$} \\
\hline & $6 \%$ & $8 \%$ & $11 \%$ \\
\hline $\begin{array}{l}\text { Water } \\
0.25 \%\end{array}$ & $\begin{aligned} y= & 2.1714 x+68.196 \\
& \text { Chitosan } \\
y= & 2.3431 x+64.208\end{aligned}$ & $y=2.0684 x+64.886$ & $\begin{array}{l}y=3.234 x+57.077 \\
y=2.8742 x+59.165 \\
y=2.7616 x+59.254\end{array}$ \\
\hline $0.50 \%$ & $\begin{array}{c}\text { Chitosan } \\
y=2.4204 x+60.868 \\
y=3.0597 x+56.620\end{array}$ & $\begin{array}{l}y=2.7012 x+62.143 \\
0.75 \% \text { Chitosan } \\
y=3.5639 x+52.055\end{array}$ & $\begin{array}{l}y=3.4545 x+54.006 \\
-\end{array}$ \\
\hline
\end{tabular}

Table 5

Estimated time to reach a $K$ value of $77 \%$.

\begin{tabular}{llll}
\hline \multirow{2}{*}{ Treatment } & \multicolumn{4}{l}{ Time to $K=77 \%$ (weeks) } \\
\cline { 2 - 4 } & $6 \%$ & $8 \%$ & $11 \%$ \\
\hline Water & 4.1 & 6.2 & 5.9 \\
$0.25 \%$ Chitosan & 6.4 & 5.5 & 6.4 \\
$0.50 \%$ Chitosan & 5.5 & 6.7 & 6.7 \\
$0.75 \%$ Chitosan & - & 6.7 & 7.1 \\
\hline
\end{tabular}

ples. The amount of coating applied for the same type of coating did not seem to affect the $K$ value evolution.

Linear trend lines were adjusted to the experimental data (Table 4).

Table 5 shows the time required to reach half the increase from the initial $K$ value and $100 \%$, calculated based on the trend lines. A three weeks difference was obtained between the worst situation when salmon samples were treated with $6 \%$ of water solution and the best result with $11 \%$ of $0.75 \%$ chitosan solution. Generally, the higher the chitosan concentration, the higher the time required to reach the established $K$ value. With respect to coating uptake, the effects were not clear.

\section{Conclusions}

Although the storage temperature defined $\left(-5^{\circ} \mathrm{C}\right)$ was much higher than that established for frozen fish preservation $\left(-18^{\circ} \mathrm{C}\right)$, it still inhibited microbial activity, keeping salmon samples below the maximum microbiological limit recommended for frozen fish. This prevented observing the influence of the type and amount of coating applied on the microbiological growth.

The $\mathrm{pH}$ value of untreated salmon during storage indicated a good preservation of muscle. The type and the amount of coating applied did not influence the evolution of $\mathrm{pH}$. The TBA value of salmon samples indicated that the amount and type of coating applied had no statistically significant influence on lipid oxidation control, meaning that it is not necessary to use high amounts of coatings to inhibit lipid oxidation.

The TVB-N values remained stable for all treatments, far below the limit of acceptability established for salmon, indicating a good state of fish preservation. No differences were observed among the various treatments applied.

The $K$ index increased during the storage period nearly reaching $100 \%$ in all treatments. The high $K$ values indicated an advanced stage of ATP degradation. The amount of coating applied for the same type of coating did not affect the $K$ value evolution.

Chitosan coatings showed to be a better option than water coating to protect salmon from dehydration in pilot-scale tests. In percentage of coating applied, the coating loss of chitosan treatments was smaller. The weight of coating lost was shown to increase with the amount of coating applied.

\section{References}

Blond, G., Meste, M., 2004. Principles of Frozen Storage. In: Hui, Y.H., Cornillon, P. Legarreta, I.G., Lim, M.H., Murrell, K.D., Nip, W.-K. (Eds.), Handbook of Frozen Foods. Marcel Dekker Inc., New York, pp. 35-63.

Brunsø, K., Hansen, K.B., Scholderer, J., Honkanen, P., Olsen, O., Verbeke, W., 2008. Consumer attitudes and seafood consumption in Europe. In: Børresen, T. (Ed.), Improving Seafood Products for the Consumer. Woodhead Publishing Limited, England, pp. 16-18.

Directive 95/149/EC, 1995. Fixing the total volatile basic nitrogen (TVB-N) limit values for certain categories of fishery products and specifying the analysis methods to be used. Official Journal of the European Communities.

Doré, B., 2008. Introduction to Part III: ensuring seafood safety. In: Børresen, T. (Ed.), Improving Seafood Products for the Consumer. Woodhead Publishing Limited England, pp. 185-193.

Dutta, P.K., Tripathi, S., Mehrotra, G.K., Dutta, J., 2009. Perspectives for chitosan based antimicrobial films in food applications. Food Chemistry 114, 11731182.

Gonçalves, A.A., Gindri Junior, C.S.G., 2009. The effect of glaze uptake on storage quality of frozen shrimp. Journal of Food Engineering 90, 285290.

Gonçalves, E.M., Abreu, M.J., Brandão, T., Silva, C.L., 2011. Degradation kinetics of colour, vitamin C and drip loss in frozen broccoli (Brassica oleracea L. ssp. Italica) during storage at isothermal and non-isothermal conditions. International Journal of Refrigeration 34, 2136-2144.

Guzmán-Chozas, M., Vicario-Romero, I.M., Guillén-Sans, R., 1998. 2-Thiobarbituric Acid Test for Lipid Oxidation in Food: Synthesis and Spectroscopic Study of 2Thiobarbituric Acid-Malonaldehyde Adduct. Journal of the American Oil Chemists' Society 75, 1711-1715.

Huss, H.H., 1995. Quality and quality changes in fresh fish. FAO Fisheries Technical Paper - 348, Rome.

Hwang, J.K., Shin, H.H., 2000. Rheological properties of chitosan solutions. KoreaAustralia Rheology Journal 12, 175-179.

ICMSF, 1986. Microorganisms in Foods 2. Sampling for Microbiological Analysis: Principles and Specific Applications (2nd ed.), University of Toronto Press, New York.

ISO 4833, 2003. Microbiology of food and animal feeding stuffs - Horizontal method for the enumeration of microorganisms - Colony-count technique at $30^{\circ} \mathrm{C}$ International Organization for Standardisation.

Jacobsen, S., Fossan, K.M., 2001. Temporal variations in the glaze uptake on individually quick frozen prawns as monitored by the CODEX standard and the enthalpy method. Journal of Food Engineering 48 227-233.

Jay, J.M., Loessner, M.J., Golden, D.A., 2005. Modern Food Microbiology, 7th ed., Food Science Text Series, USA.

Jiang, S.-T., Lee, T.-C., 2004. Freezing seafood and seafood products: principles and applications. In: Hui, Y.H., Cornillon, P., Legarreta, I.G., Lim, M.H., Murrell, K.D., Nip, W.-K. (Eds.), Handbook of Frozen Foods. Marcel Dekker Inc, New York, pp. 248-298.

Johnston, W.A., Nicholson, F.J., Roger, A., Stroud, G.D., 1994. Freezing and refrigerated storage in fisheries. FAO Fisheries Technical Paper - 340, Rome.

Kilincceker, O., Dogan, I.S., Kucukoner, E., 2009. Effect of edible coatings on the quality of frozen fish fillets. LWT - Food Science and Technology 42, 868873.

Leroi, F., Jofftaud, J., Arboleya, J., Amarita, F., Cruz, Z., Izurieta, E., Lasagabaster A., Martínez de Marañón, I., Miranda, I., Nuin, M., Olabarrieta, I., Lauzon, H. Lorentzen, G., Bjørkevoll, I., Olsen, R., Pilet, M., Prévost, H., Dousset, X. Matamoros, S., Skjerdal, T., 2008. Hurdle technology to ensure the safety of seafood products. In: Børresen, T. (Ed.), Improving Seafood Products for the Consumer. Woodhead Publishing Limited, England, pp. 399-426.

Martins, R.C., Lopes, I.C., Silva, C.L.M., 2005. Accelerated life testing of frozen green beans (Phaseolus vulgaris, L.) quality loss kinetics: colour and starch. Journal of Food Engineering 67, 339-346.

NP 2930, 2009. Produtos da pesca e da aquicultura - Determinação do teor de azoto básico volátil total (ABVT) - Método de Conway. Instituto Português da Qualidade.

Olafsdóttir, G., Martinsdóttir, E., Oehlenschläger, J., Dalgaard, P., Jensen, B. Undeland, I., Mackie, I.M., Henehan, G., Nielsen, J., Nilsen, H., 1997. Methods to evaluate fish freshness in research and industry. Trends in Food Science and Technology 8, 258-265.

Pavlath, A.E., Orts, W., 2009. Edible Films and Coatings: Why, What, and How? In: Embuscado, M.E., Huber, K.C. (Eds.), Edible Films and Coatings for Food Applications. Springer, New York, pp. 1-23.

Pokorny, J., Dieffenbacher, A., 1989. Determination of 2-thiobarbituric acid value: direct method. Pure and Applied Chemistry 61, 1165-1170.

Rodriguez-Turienzo, L., Cobos, A., Moreno, V., Caride, A., Vieites, J.M., Diaz, O., 2011 Whey protein-based coatings on frozen Atlantic salmon (Salmo salar): influence of the plasticiser and the moment of coating on quality preservation. Food Chemistry 128, 187-194.

Ryder, J.M., 1985. Determination of adenosine triphosphate and its breakdown products in fish muscle by high-performance liquid chromatography. Journal of Agricultural and Food Chemistry 33, 678-680. 
Sathivel, S., Liu, Q., Huang, J., Prinyawiwatkul, W., 2007. The influence of chitosan glazing on the quality of skinless pink salmon (Oncorhynchus gorbuscha) fillets during frozen storage. Journal of Food Engineering 83, 366-373.

Shahidi, F., Arachchi, J.K.V., Jeon, Y.J., 1999. Food applications of chitin and chitosan. Trends in Food Science and Technology 10, 37-51.

Singh, R.K., Balange, A.K., 2005. Characteristics of pink perch (Nemipterus japonicus) surimi at frozen temperature. Journal of Food Processing and Preservation 29, $75-83$.
Souza, B.W.S., Cerqueira, M.A., Ruiz, H.A., Martins, J.T., Casariego, A., Teixeira, J.A., Vicente, A.A., 2010. Effect of Chitosan-Based Coatings on the Shelf Life of Salmon (Salmo salar). Journal of Agricultural and Food Chemistry 58, 11456-11462.

Tsironi, T. Dermesonlouoglou, E., Giannakourou, M., Taoukis, P., 2009. Shelf life modelling of frozen shrimp at variable temperature conditions. LWT - Food Science and Technology 42, 664-671. 